\title{
IMPACT OF GREEN ROOF ON HEATING AND COOLING IN CONTEXT OF DIFFERENT CLIMATIC ZONES IN INDIA
}

\author{
Ar. Ankur Bhardwaj ${ }^{1}$, Dr. Shweta Chaudhary ${ }^{2}$, Ar.Kirti Varandani ${ }^{3}$ \\ ${ }^{1,2 \& 3}$ CODE, Vivekananda Global University ,Jaipur, Rajasthan, (India).
}

Article DOI: https://doi.org/10.36713/epra7466

DOI No: $10.36713 /$ epra7466

\begin{abstract}
The ecological, social and visual commitments that green roofs can make towards sustainable living in more intensified urban centres are generally recognized around the world. Green roof is one such sustainable methodology, utilization of which causes us in insulating the buildings and, subsequently contributing to better energy proficient execution of the same. Green roofs additionally give environment to various species, lessen the rainwater runoff and better deal with the carbon-dioxide cycle. In spite of these advantages, 'Green roofs' are not as basic an element in India as they are in other European and American urban areas. In this paper an attempt has been made to enhance the advantages of this innovation in India.

Green roofs systems looks simple in terms of setting up, but actually very complex in maintaining and achieving sustainability. In depth study of green roofs, historic background, climatic zones, impacts of green roofs on heating and cooling, benefits, problems and opportunities is done with the help of data taken from secondary sources like books, magazines and published literature (articles, journals, conference proceedings) form various elibraries and other online platforms.
\end{abstract}

KEY WORDS: Heating, Cooling, Green Roofs, Sustainability)

\section{INTRODUCTION}

Green infrastructure uses vegetation, soils, and natural processes to manage water and create healthier urban environments, providing traditional roof services and alternative storm water management technologies. Currently, climate change and the scarcity of natural energy resources are topics of interest in many countries. Furthermore, cities continue to grow and expand their peripheries to accommodate increases in rural migration to urban area. (CasconeOrcID, 2019).

The percentage of population that lives in the urban areas at present, there is unavailability of greens in the country. This situation has led to the lack of greenery. In short, we can say that there has been blocking of the urban environment which has led to rise in the temperature and thus ecology has been disturbed. (Vijayaraghavan, 2016).
Thus there is need for climate responsive design techniques and use of local and sustainable materials to overcome the issue of urbanisation and climate change. Increase in the vegetation can help to combat the problem. Thus green roofs fit best for the Indian scenario where the development is taking place at a very high pace and thus effecting the climate as here Structures represent $35 \%$ of total energy utilization in the country now, thus structure's energy use is developing at $8 \%$ yearly. (Himanshu Poptani, 2014). 
It is one such sustainable approach, use of which helps us in insulating the buildings and, thereby contributing to better energy efficient performance of the building. Green roofs can help to mitigate the heat island effect in cities and other constructed areas with minimal vegetation, especially during the day. (Agency, n.d.).

The benefits of green roofs in cities have been split into seven categories: thermal impacts, rainfall drainage, and aesthetics.

Others include design and building, plants (flora), noise reduction, and air pollution abatement. . (Wiecek, 2019)

Relationship of the building envelope with the encompassing climatic conditions is liable for the comfortable environment. The rooftop has been discovered to be the main underlying component of structures in a hot climate by displaying and recreation of energy streams in present day homes. (Reddy, 2004)

The growing number of buildings in metropolitan areas with green roofs adds to the expansion of biologically active areas while also lowering the average ambient temperature. The consequences of the urban heat island are reduced as a result, the use of green roofs in cities will also be conducive to the protection of biodiversity in urban areas. (Wiecek, 2019)

\section{CO-RELATION OF GREEN ROOFS WITH CLIMATIC ZONES}

Taking the case of UK, the built structures are answerable for 45 percent of $\mathrm{CO} 2$ discharges. A high extent of these emanations are from heating and cooling the internal climate. Lessening the energy utilization of the UK's built structures will decrease their commitment to environmental change. The IPCC (Intergovernmental Panel on Climate Change) had discovered that structures give probably the best, cost- effective and quickest freedoms to handle environmental change. Thus Green roofs can fundamentally diminish the cooling heaps of structures, bringing about decreased air cooling prerequisites and hence decreased energy utilization and the related yield of environmental carbon dioxide.(www.ukgbc.org ).The other example can be the colder environments of London, Moscow and Montreal advantage the least, arriving at daytime normal reductions from 1.7 to $2.10 \mathrm{C}$ and maxima from 2.6 to $3.2 \mathrm{o} \mathrm{C}$ for the green-walls case and from 3.0 to $3.80 \mathrm{C}$ and from 3.6 to 4.5 o $\mathrm{C}$, separately. It may be said that, the more hotter and drier an environment is, the more significant the impact of living roofs on moderating cities temperatures is.(Alexandri and Jones, 2008)

Green roofs have a positive function in rooftop thermal conduct in various environments which the pace of their productivity relies upon the environment that they are situated in. (Ahmadi et al., 2015). Our country is home to a phenomenal assortment of climatic zones, going from sub-tropical in the south to sub-mild mountains in the Himalayas. In view of the geological highlights, the nation is grouped into 15 Agro climatic zones with 20 Agro natural zones and 72 sub divisions. Unquestionably, Indian homesteads face an assortment of climate limits because of huge variety in climatic conditions. As indicated by NBC 2016, climatic zones in our nation are isolated into 5 zones. Each climatic zone doesn't have same environment for the entire year; it has a specific season for over a half year and may encounter different seasons for the leftover time frame. (NBC, 2017)

The significant job of a green rooftop like some other rooftop is to give cover from heat, cold, day off, and wind. A green rooftop is just a convective roof with soil and plant layers in addition to a waterproofing covering. Green rooftops as referenced before relies upon different boundaries like protection, vegetation type etc. All of these parameters fluctuate and are affected by the environment zone they are found. Contractors and Clients in spite of the fact that comprehend the significance of a living roof, they don't have truly necessary information in regards to the variety in green rooftop development concerning the environment to profit the most extreme investment on energy. Having accurate information about the various types of green rooftop development based on the climatic zones in which they are located can benefit in terms of energy savings and so make it more monetary. This would overall be able to expand the development of these living rooms across the globe. Since green rooftop relies upon soil creation, plant type, climatic condition, and so forth on location estimated information needs to be gathered before installing the living roofs on the structure or any building. The measure of warmth sent into or lost from a structure differs with the change from day to evening time temperatures and changes through fluctuating climate, for example heating by daylight and cooling by wind. The appropriate design and determination of a building envelope is a proficient way to decrease the space heating cooling loads (Kaynakli 2012).

The principle design factors that should be considered for plan of energy productive structures are dividers, rooftop, arrangement and size of openings, proportion of window/divider territory and arrangement of legitimate concealing gadgets. These components have been talked about finally in past section. Green roofs most ordinarily alludes to vegetative rooftop frameworks that contain live plants on the rooftop layer. Vegetative rooftops are 


\section{EPRA International Journal of Research and Development (IJRD)}

named either serious or broad, in light of planting medium profundity. Intensive vegetative rooftops are the more considerable rooftop regular and oblige the development of trees and bushes. They require a planting mechanism of at any rate 1 foot inside and out and can reach up to 3 feet top to bottom. Extensive vegetative green rooftops are more slender, lighter frameworks utilizing vegetation of grasses or sedums that have shallower root structures (Cavanaugh 2008).

The Green roofs have been examined from a very long time in numerous urban communities around the planet as an instrument to take care of numerous issues in the cities climate. The green rooftops introduced a comparative picture with respect to their mid-year surface temperatures in warm and humid and hot and dry climates. Another investigation on life cycle evaluation of green rooftops proposed that they are as of now not cost effective on a private expense premise, however multifamily and business building green rooftops are serious when social advantages are incorporated (Blackhurst et al. 2010).

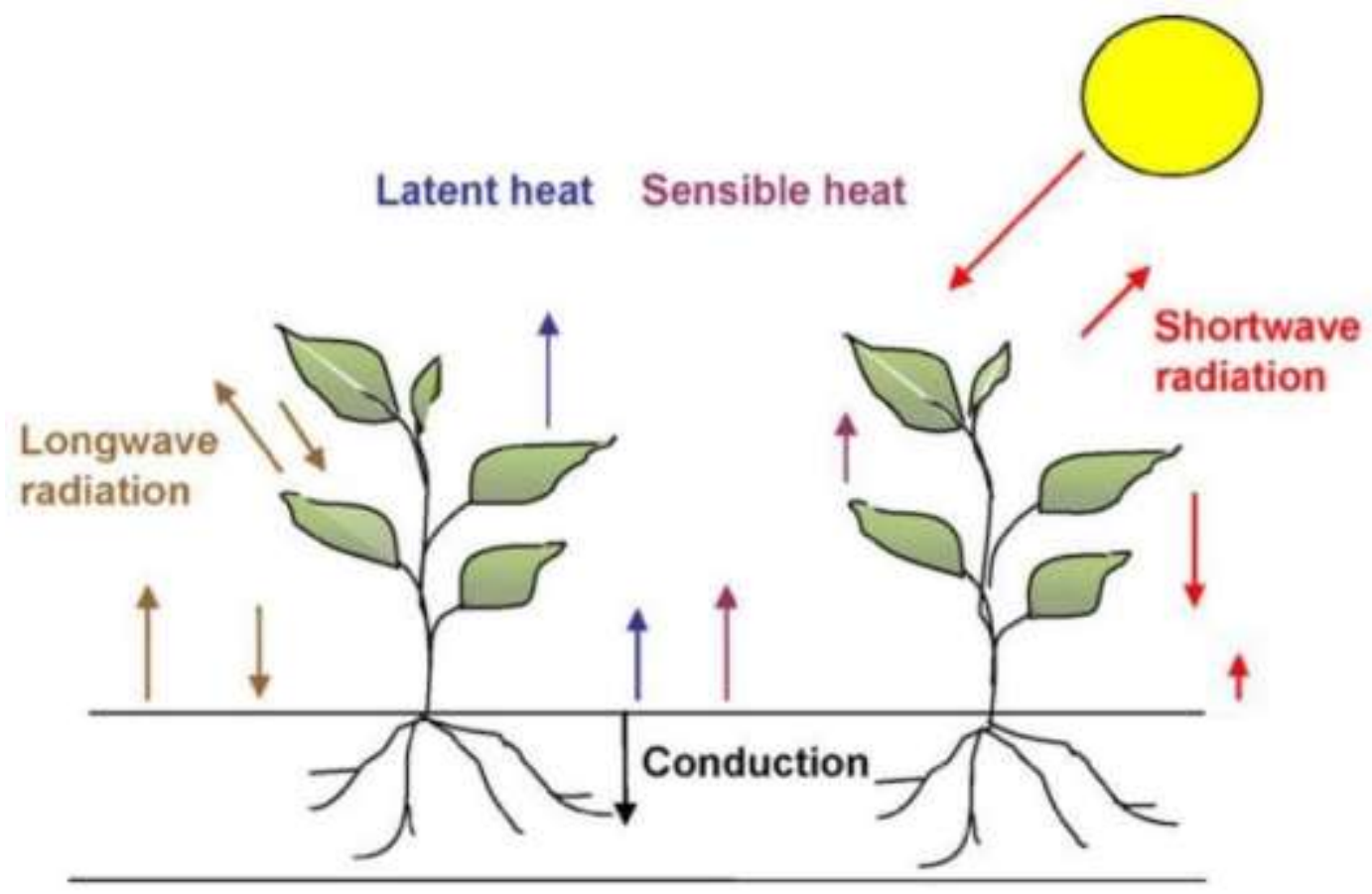

Figure 2 Surface energy Balance of green RoofsSource: Source: Stuart et al., 2009

Analyses directed by Stuart et al. (2009) showed that the warmth balance technique utilizes the guideline of energy preservation to ascertain heat moves and the convective warmth streams are controlled by heat move condition for surface and air temperatures in various climatic zones. The hydrologic water vanishing technique is supported for observing the impact of long haul energetics because of vegetation changes.

Different numerical examinations have been done on ventilated lightweight low inclined rooftop, ventilated rooftop without warm protection and air temperature variety with ventilated cavity. Numeric studies demonstrated that energy saving surpassing $30 \%$ can be accomplished by utilizing ventilated rooftops in summer, contrasted with a similar non ventilated design. Normally ventilated pit rooftop was discovered to be better than the single rooftop in bringing down the usable temperature. (Susanti et al. 2008, 2010, 2011). A venturi formed rooftop can drive the normal ventilation of the structure zones. This rooftop idea into the system has been talked about by Bronsema (2010). Diverse plan setups of the venturi shaped rooftop were examined: without controlling vanes, with managing vanes at each 900 span and with directing vanes at each 100interval etc. The numerical studies indicated that expanding vent size brings about higher ventilation wind current rate however doesn't affects the attic heating load, and both adequate ventilation and protection are expected to guarantee the appropriate function and its energy effectiveness (Wang et al. 2012).

The vaulted rooftop and level rooftop in different climatic conditions demonstrated that vaulted rooftops are just appropriate for hot and dry environments, because of the presence of bigger 
pillar part of the sun oriented radiation which is successfully reflected by the bended rooftop surface, and lessfor warm and sticky environments. In hot and dry climatic conditions vaulted and domed rooftops are very mainstream in the vernacular design. Vaulted rooftops assimilate more warmth during the daytime than level rooftops, they additionally disseminate more warmth through characteristic convection and re- radiation particularly during evenings in run of the mill desert environment that encounters colder encompassing temperatures. High warm separation happens inside vaulted rooftop structures, with practically $75 \%$ of the delineation occurring in the volume under the vault, keeping the lower a piece of the structure space cool. The hot air can be depleted close to the highest point of the peak dividers of vaults (Tang et al. 2006).

\section{IMPACTS OF GREEN ROOFTOPS ON HEATING AND COOLING UTILIZATION OF STRUCTURES}

Generally, green rooftops were known for capacity of giving warm protection in cold environments and to shield from overheating because of the high sun oriented openness of rooftops in warm environments. These properties were greatly valued in times when thermal insulation materials and 'cool' materials were not accessible. In current period, these properties are as yet viewed as the principle benefits that a green rooftop can give to a structure, however as of not long ago this information had just a subjective character since there could have been no additional data to report this position. (Theodosiou, 2009)

The requirement for more proficient and harmless to the ecosystem urban structure needs to achieve the goal of sustainability, researchers have been examining green rooftop innovation to convert data from a subjective to a quantitative structure in order to abuse and enhance the commitment of green rooftops to the energy execution of buildings. (Issa et al., 2012)

India has all the climates of the world, however the climate in a large portion of the nation is really tropical and influenced by the rainstorm system, with a dry and a rainy season. The rains are exceptional and enduring relying upon zone, and wettest period is from July to September, besides in the southeast, where the withdrawing rainstorm proceeds until the year's end. The hottest period by and large runs from April to mid-June, for example prior to the appearance of the rainstorm, so the schedule's spring is in a way the genuine summer. Winter period is from December to February. (NCERT, 2020)

\section{CONCLUSION AND FUTURE CONSIDERATIONS}

Sustainability is a very broader area and open ended, likewise one cannot achieve it in a single day or by focusing on a particular thing but it can be achieved with a holistic approach by practicing various elements and factors of the same. Green roof is also a milestone in the path to reach sustainable future. There is a gap in the green roof technology i.e. climate responsive green roof or we can say adaptability of green roof technology according to different climatic zones. With the above study it is clear that we can achieve more sustainable green roof which will be beneficial in every term such as environmental benefits, reduction of pollution, cost effectiveness, low maintenance and also better energy performance which will lead to a better building envelope and if practiced in every building, we can also achieve a sustainable urban envelope. To further study and analyze the relation of green roofs with respect to climatic zones, a detailed research can be done by taking a specific case of a climatic zone to analyze and frame the strategies for efficient climatic responsive green roof technologies in the field of architecture for a sustainable and healthy future.

\section{REFERENCES}

1. Al-Kodmany, M. M. (2012). Tall Buildings and Urban Habitat of the 21st Century: A Global Perspective. Buildings, 384-423.

2. Areas-Review, T. I. (2009). Dariusz Suszanowicz and Alicja Kolasa Wiecek. Atmosphere, 1-17.

3. Burn, T. E. (2003). Permafrost. Elsevier Science, 1717-1730.

4. CABA. (2021, February 1). Climate Association Business Association. Retrieved from cabaus.org: cabaus.org

5. Cascone, S. (2019). Green Roof Design: State of the Art on Technology and Materials. Sustainability, 1-27.

6. Environmental Protection Agency, United States. (2021, January 21). United States Environmental Protection Agency. Retrievedfrom epa.govin: https://www.epa.gov/heatislands/using-greenroofs-reduce-heat-islands

7. Himanshu Poptani, A. B. (2014). Extensive Green Roofs: Potential for Thermal and Energy benefits in buildings in central India. 30th INTERNATIONAL PLEA CONFERENCE 1618 December 2014, CEPT University, Ahmedabad (pp. 1-8). Ahmedabad: CEPT University.

8. Livingroofs.org. (2021, February16). https://livingroofs.org. Retrieved from Livingroofs.org: https://livingroofs.org/energyconservation/

9. Musa Akther, J. H. (2018). A Review of Green 
Roof Applications for Managing Urban Stormwater in Different Climatic Zones. sustainability, 1-28.

10. NBC. (2017). NATIONAL BUILDING CODE OF INDIA 2016. CHENNAI: BIS for LARSEN AND TOUBRO CONSTRUCTION MANAPAKKAM.NCERT.(2020,December29).C limate-NCERT. Retrieved fromncert.nic.in: https://ncert.nic.in/ncerts/l/iess104.pdf

11. Rufai Mohammed Ahmed, A. P. (2016). An Evaluation of Green roofing in Buildings. International Journal of Scientific and Research Publications, Volume 6, Issue 1, 366-373.

12. Theodosiou, T. (2009). Green Roofs in Buildings: Thermal and Environmental Behaviour. Advances in Building Energy Research, 271-288.

13. United Nation Human Settlement Programme. (2008). Best Practices on Social Sustainablity. Illus: UNESDOC.

14. Vijayaraghavan,K.(2016).Greenroofs:A critica lreview on the role of components, benefits ,limitations and strends.

RenewableandSustainableEnergyReviews, 740752. 